\title{
Stream Restoration Databases and Case Studies: A Guide to Information Resources and Their Utility in Advancing the Science and Practice of Restoration
}

\author{
Robin G. Jenkinson, ${ }^{1,2}$ Katie A. Barnas, ${ }^{3}$ Jeffrey H. Braatne ${ }^{1}$ Emily S. Bernhardt ${ }^{4}$ \\ Margaret A. Palmer, ${ }^{5}$ J. David Allan, ${ }^{6}$ and The National River Restoration \\ Science Synthesis ${ }^{7}$
}

\begin{abstract}
The successful application of adaptive management to the science and practice of restoration ecology requires specific knowledge about the outcomes of past restoration efforts. Ideally, project results would be readily available to scientists or other project managers with similar goals or in analogous ecosystems. Recently, there has been a proliferation of Internet-accessible databases, lists, and case studies of stream and river restoration projects. These resources include a wide range of information that could be accessed to aid natural resource and conservation professionals in restoration. In the U.S. Pacific Northwest, the National Marine Fisheries Service's Northwest Fisheries Science Center and, on a national scale, the National River Restoration Science Synthesis are combining existing national and regional databases, along with the individual
\end{abstract}

project descriptions, to create comprehensive, web-based databases of stream restoration projects. In this process, more data sources were discovered than fit the scope of either of these projects. Ten international, 19 U.S. national, and 42 U.S. regional web-accessible sources of restoration project databases and case studies are listed in this study. However, to easily use information that is currently scattered in multiple files and Web sites, databases would optimally use a common, standardized format. We provide a recommended list of information to be included in restoration databases. These efforts may provide a blueprint for development of compatible international databases of stream restoration projects.

Key words: adaptive management, database, National River Restoration Science Synthesis, stream restoration.

\section{The Need for Stream Restoration Databases} and Case Studies

Major efforts have been initiated throughout the world to maintain and improve the ecological integrity of streams by restoring natural fluvial and landscape processes (NRC 1992; Henry et al. 2002). Bernhardt et al.

\footnotetext{
${ }^{1}$ University of Idaho, Department of Fish, Wildlife and Range Resources, P.O. Box 4441136, Moscow, ID 83844-1136, U.S.A.

${ }^{2}$ Address correspondence to R. G. Jenkinson, email jenk8856@uidaho.edu

${ }^{3}$ Northwest Fisheries Science Center, NOAA Fisheries, 2725 Montlake Blvd E, Seattle, WA 98112, U.S.A.

${ }^{4}$ Department of Biology, Duke University, Durham, NC 27708, U.S.A.

${ }^{5}$ Department of Entomology, University of Maryland, PLS Building 4112,

College Park, MD 20742-4454, U.S.A.

${ }^{6}$ School of Natural Resources, University of Michigan, Ann Arbor,

MI 48109, U.S.A.

${ }^{7}$ The National River Restoration Science Synthesis is an NSF NCEAS working group with additional funding support from Altria, the USGS, the David and

Lucile Packard Foundation, CalFED, the C. S. Mott Foundation, the

McKnight Foundation, and the US EPA. Members include M. A. Palmer,

J. D. Allan, E. S. Bernhardt, G. Alexander, S. Brooks, J. Carr, S. Clayton,

C. Dahm, J. FollstadShah, D. L. Galat, S. Gloss, P. Goodwin, D. Hart, B. Hassett,

R. Jenkinson, G. M. Kondolf, S. Lake, R. Lave, J. L. Meyer, T. K. O'Donnell,

L. Pagano, and E. Sudduth.
}

(C) 2006 Society for Ecological Restoration International
(2005) found that on average, more than 1 billion dollars are spent each year on stream restoration in the United States. Restorationists have recognized the need for postproject monitoring and reporting to improve future restoration projects and share lessons learned with other practitioners (Kondolf \& Micheli 1995; Landers 1997; Lake 2001).

Databases and case studies of restoration projects enable restorationists to save money, time, and effort by avoiding mistakes made by others; to adopt proven strategies to improve their probability of success; and to know about past projects conducted within their watershed to coordinate efforts (Clewell \& Rieger 1997). River expert, Luna Leopold, spoke about this opportunity in 1997:

"We have a problem in river restoration .... The problem is lack of communications and trading of experiences. As a result, successes in field restoration are little known, while mistakes are repeated indefinitely ....

What is needed is a gradually accumulating file of case studies describing with text the illustration of the original condition, an assessment of the basic 
cause of the problem, the techniques and construction details of treatment, and an objective analysis of the result." (Leopold 1997)

Regional project information also sheds light on the performance of specific species or techniques, in addition to sources of local materials, contractors, and volunteers. Therefore, even an ecologically unsuccessful project may be termed a partial success if it improves future project design (Palmer et al. 2005).

Knowledge of where different activities have been implemented in a watershed can help inform conservation planning. With specific location information from a restoration database, future restoration projects could be designed to link areas of higher ecological integrity, thereby extending the effectiveness of restoration efforts. This allows new restoration activities located in areas without previous restoration to be successfully monitored without prior projects masking or confounding observed results. Also, knowledge of past or ongoing restoration activities would help prevent the implementation of projects that may cause detrimental effects on projects underway downstream.

Databases could also demonstrate the value of improving the integrity of stream ecosystems to funders and policymakers. Costs could be assessed and evaluated against reported social and environmental successes. Such evaluations could provide greater information for making annual budgetary recommendations for programs that fund restoration projects. Information contained within databases also could aid the prioritization of how and where to allocate limited restoration (e.g., a particular stream reach that could link existing projects or a critical but underfunded program area). Improved accessibility and exchange of information on specific restoration projects will increase the scientific understanding of stream ecosystems along with the collective ability to conduct successful projects (Kershner 1997; Leopold 1997; FISRWG 2001).

The objectives of this study are 3-fold: (1) to provide a listing of publicly available international, U.S. national, and U.S. regional databases on river and riparian restoration; (2) to discuss the challenges of available databases; and (3) to provide recommendations on fields of information to be included in restoration databases, thereby improving their usefulness to restoration practitioners, conservationists, funders, and policymakers.

\section{Methods}

This study is a result of projects conducted by the National River Restoration Science Synthesis group (NRRSS) and National Oceanic and Atmospheric Administration's (NOAA) National Marine Fisheries Service's Northwest Fisheries Science Center (NWFSC). The NRRSS project consists of a team of university scientists and graduate students from the United States and Australia, who compiled information on river and riparian restoration activities occurring in the past 30 years to characterize the practice of river restoration and identify common elements of successful river restoration projects. NRRSS identified databases, lists, and case studies of river restoration projects using Internet searches, networking, and phone calls (see Bernhardt et al. 2005, for a more detailed description). The information contained within collected data sources was entered into a database housing more than 14,000 project records.

Concurrently, the NWFSC developed a separate database, in partnership with the NRRSS project, which includes information on 23,000 projects in the states Oregon, Washington, Idaho, and Montana. Driving this project was the designation under the Endangered Species Act of more than 20 "evolutionarily significant units" of salmon and steelhead as endangered or threatened within the Pacific Northwest. The NWFSC Pacific Northwest Salmon Habitat Project Tracking Database was developed to improve regional tracking and evaluation of the effectiveness of stream restoration. The 23,000 project records of various formats were transformed into a single spatially explicit prototype database designed to be compatible with the NRRSS database. More than 37,000 project records covering all the United States and Southeast Australia makeup the combined NRRSS/NOAA NWFSC dataset (Bernhardt et al. 2005).

\section{International, U.S. National, and U.S. Regional Databases and Case Studies}

In the process of compiling the NWFSC and NRRSS databases, we encountered numerous web-accessible databases, many more than fit the scope of our projects. The title of each source, its web address, the number of restoration projects described, and a short description are listed for 10 international databases in Table 1, 19 U.S. national databases in Table 2, and 42 U.S. regional databases in Table 3. Approximately 23 of the 71 sources listed include case studies. International databases are those that cover either the whole or the parts of a single country other than the United States (e.g., The Danish Centre for River Restoration) or those that contain records for multiple countries (e.g., the Community Mapping Network Project Directory). U.S. national databases include databases of projects by federal agencies, nongovernmental organizations, and corporations specializing in restoration. Finally, the majority of U.S. regional sources (33) are either state government agencies or state-based organizations.

\section{Challenges Associated with Using Current Databases}

Progressively, more and more electronic databases are being developed explicitly to track river restoration and to allow the transfer of information on restoration projects across basins, ecoregions, and continents. In the United 
Table 1. International databases and case studies of stream restoration projects.

Community mapping network project directory

www.shim.bc.ca/

Map with flags around the globe that link to summarized project reports

Danish Centre for River Restoration

Danish River Restoration Projects Database

www2.dmu.dk/1_om_dmu/2_tvaer-funk/3_vlres/database/restaurering.asp

Includes name of stream/basin, UTM coordinates, project type and

activity, completion year, cost, stream discharge, and catchment area.

It is only updated to 1998 and is not available in English

Denmark Ministry of Environment and Energy, National Environmental Research Institute

River Restoration; Danish Experience and Examples

www2.dmu.dk/1_viden/2_Publikationer/3_Ovrige/rapporter/River_Restoration_UK_3a.pdf

Case studies of river restoration projects

Fisheries Project Registry, British Columbia, Canada

www.canbcfpr.pac.dfo-mpo.gc.ca/fpr

Searchable database that provides map location and project contact information

Land and Water Australia Project JCU 15

Travelling Fellowship Report-Trips to Europe and North America

January 2001 and June 2002 by Ross Kapitzke

www.rivers.gov.au/research/rlrd/streamrehab.htm

Kapitzke visited nine restoration sites around Europe and three sites in North America, and numerous river restoration professionals in order to learn and compare Australian

methods with other approaches

Ontario Streams

www.ontariostreams.on.ca/demoprojects.html

Status reports on restoration projects

River Restoration Centre, United Kingdom

RRC Projects Database and Demonstration Project Case Studies

www.therrc.co.uk/r_y p.htm

Contains brief summaries and case studies. Not publicly available over the web

www.therrc.co.uk/demonstration_projects.php

Five detailed case studies of projects in Great Britain and Denmark

Rocky Mountain Institute

Daylighting: New Life for Buried Streams

www.rmi.org/sitepages/pid172.php

This report reviews the benefits, challenges, and costs of "daylighting"

formerly culverted or buried streams and includes case studies of

several dozen projects from around the United States and internationally

Stewardship Centre for British Columbia, Canada, Case Study Library

www.stewardshipcentre.bc.ca/caseStudies/studySearch.asp

Location and descriptive information for each project, then results of the study

The Nature Conservancy

nature.org/initiatives/freshwater/work/

Case studies of freshwater conservation projects in North and South America through a linked map

USFWS Division of Bird Habitat Conservation

North American Wetlands Conservation Act Grants Program

www.fws.gov/birdhabitat/NAWCA/grants.htm

Projects, which are mostly in Canada, United States, and Mexico, are listed in biennial reports

UTM, Universal Transverse Mercator; USFWS, U.S. Fish and Wildlife Service.

States, among others, the Army Corps of Engineers, the U.S. Forest Service, the Bureau of Land Management, and the National Park Service are currently working to create databases for their river restoration projects. The
European River Restoration Network is also developing a river restoration database.

The wide variety of activities associated with stream restoration makes compilation of project descriptions and 
Table 2. U.S. national databases and case studies of river restoration projects.

American Rivers Restoration Resource Center www.americanrivers.org/site/PageServer?pagename $=$ AMR_content_7ba0 River restoration success stories

Ducks Unlimited www.ducks.org/Regions/index.asp

Riparian and upland restoration projects and many more pond and wetland restoration projects. They offer maps of past project locations

EPA

Restoration Project Directory

yosemite.epa.gov/water/restorat.nsf/rpd-2a.htm?OpenPage

Includes the Mid-Atlantic Integrated Assessment

EPA Five-Star Restoration Projects www.epa.gov/owow/wetlands/restore/5star/states.html Projects are listed by state

EPA National Showcase Watersheds www.epa.gov/owow/showcase/projects.html Includes detailed project descriptions for 12 projects in 11 states.

They also list projects in 40 case study watersheds

Federal Highway Administration Transportation Enhancement Program www.enhancements.org/projectlist.asp

List projects in the mitigation/wildlife crossings category, wetland restoration, stormwater mitigation, erosion control, and stream restoration categories

Inter-Fluve, Inc.

www.interfluve.com/

Descriptions of recent projects

NOAA, National Marine Fisheries Service NOAA Restoration Center Project Database seahorse.nmfs.noaa.gov/rcdb/class/location_main.html

Lists projects by state, listing funding mechanism, total grant amount, and project title and year

National Resource Conservation Service

Reinvesting in America's watersheds

www.nrcs.usda.gov/programs/ws_reinvent/index.html

Case studies of watershed restoration projects. Only 19 are highlighted, though

they write that by 1998 , NRCS had completed more than 2,000 projects

National Resource Conservation Service Buffer Success Stories

www.nrcs.usda.gov/feature/buffers/bufconts.html

Case studies of buffer projects by state

The Bioengineering Group, Inc.

www.bioengineering.com/tbg_website.htm

List of projects with photos and descriptions

9

The River Network

Success Stories and Lessons Learned

www.rivernetwork.org/library/index.cfm?doc_id=122

Stories submitted by conservationists to this Web site

The River Network

Watershed Assistance Grants Awardees, 1999-2002

www.rivernetwork.org/howwecanhelp/index.cfm?doc_id $=98$

List of projects, of which 24 are stream restoration

The River Network

Watershed Assistance Grants: Building Capacity of Community-Based

Watershed Partnerships: An Evaluation by Suzanne Easton, March 2001

www.rivernetwork.org/howwecanhelp/index.cfm?doc_id=94

Describes funded projects and highlights lessons learned 
Trout Unlimited

Dam Removal Success Stories

www.tu.org/site/pp.asp?c=7dJEKTNuFmG\&b=277845

List of 467 dam removals, with purpose, state, stream, and date. Also, 25 case studies of specific dam removal projects

Trout Unlimited

Watershed Restoration

www.tu.org/site/pp.aspx? $\mathrm{c}=7 \mathrm{dJEKTNuFmG \& b=275422}$

Case studies of current projects, organized on a clickable map of the United States

Trout Unlimited

City Streams; Trout Unlimited Urban Rivers Success Stories

www.tu.org/site/pp.asp?c=7dJEKTNuFmG\&b=2,77,845

This document highlights 12 urban restoration projects around the country and provides contact information: from Water Quality and Brook

Trout restoration in Alley Creek in New York City to a stormwater utility in River Falls, Wisconsin that charges homes and businesses according to the amount of stormwater run-off

Water Resource Development Acts

Available in the American Rivers Web site's "Corps Watch" section

www.americanrivers.org

Beginning in the 1970s, money was authorized for restoration projects. The projects are listed with name of project, description, and cost

Wildlife Habitat Council, Waterways for Wildlife

Descriptive case studies

EPA, Environmental Protection Agency; NOAA, National Oceanic and Atmospheric Administration.

results challenging. Stream restoration objectives vary among regions as well as between countries (Jungwirth et al. 2002; Shields et al. 2003). For example, within the United States, stream restoration in the Pacific Northwest focuses on restoring endangered salmon habitat, whereas Chesapeake Bay restoration centers on improving water quality (Bash \& Ryan 2002; Mayer et al. 2004; Palmer et al. 2004). Depending on the area, the same activities can be either restorative or detrimental. In Southeast Australia, exotic willow removal and bank stabilization with native plantings dominate restoration activities (Ladson et al. 1997; Bobbi 1999), whereas restorationists in other areas plant native willow species to restore riparian vegetation.

The majority of available international, national, and regional restoration databases and case studies (Tables 1-3) include basic descriptive information such as contact information, dates, location, cost, and project goals or activities. Because these databases are designed with different goals and scopes, they contain varying amounts of information and detail, which enables different levels of recall and evaluation. The level of detail in these databases tends to vary inversely with the scale of the region described. Generally, regional databases contain the most detailed information, followed by national and multinational databases. To our knowledge, Oregon and Washington currently lead the world in number, size, detail, and Internet availability of stream restoration databases (Table 3 ).
Sharing restoration knowledge through data sources available over the Internet can expand the learning potential of restoration ecology. However, given the variety of formats and data fields in existing databases, answering the question of "Where have pool habitat restoration projects occurred in the John Day River, Oregon?" could require days of searching through various Web sites to find an adequate population of projects from which to learn. For example, different Pacific Northwest databases describe location information in different ways: state, county, latitude, longitude, Township Range Section, Stream, Subbasin, Latitude-Longitude ID, Hydrologic Unit Code, and begin and end stream mile. In addition, project reporting can be complicated by the fact that multiple objectives, sites, and phases of a single project are common, and project locations on private lands may be sensitive. A single project may be reported by more than one entity or with more than one funding source with dissimilar information, causing multiple and differing listings of a given project.

As new databases are developed, the acceptance and usage of similar formats will allow information to be readily synthesized and queried to avoid overlap across databases. As part of the NRRSS project, a database structure was developed by Bruce Powell at U.S. Geological Service National Biological Information Infrastructure. The database schema is free and publicly available at http:// nrrss.nbii.gov/schema.html. This may serve as a blueprint 
Table 3. U.S. regional databases and case studies of river restoration projects.

Agency, Database Name, Contact/Web Site, and Description

Approximate No. of Records

Alaska Department of Fish \& Game

The Evaluation of Wetland and Riparian Restoration Projects

www.sf.adfg.state.ak.us/SARR/Publications/techpub.cfm

Detailed case studies with evaluation results

Appalachia, Trout Unlimited

Restoring the Wealth of the Mountains: Cleaning Appalachia's Abandoned Mines

www.tu.org/site/pp.asp?c=7dJEKTNuFmG\&b=277845

Report includes case studies of five projects

Arizona

Arizona Water Protection Fund

www.awpf.state.az.us/funded.htm

Project descriptions, a clickable map, and searchable database

Asotin Subbasin Plan, Asotin Conservation District

www.nwcouncil.org/fw/subbasinplanning/asotin/plan/

An impressive list of projects completed by this conservation district

California, CalFish Habitat Restoration Project Database

www.calfish.org

Project database located under Data, then Habitat Restoration on the CalFish Web site

California, Natural Resource Project Inventory

endeavor.des.ucdavis.edu/nrpi or www.ice.ucdavis.edu/nrpi

Includes California Ecological Restoration Projects Inventory, Watersheds Project

Inventory, and California Watershed Project Inventory. Information includes the

type of ecosystem restored, plant species used, soil and nutrient amendments, erosion

control measures, and project goals, performance standards, and monitoring data

Columbia Basin Fish and Wildlife Authority, Bonneville Power Administration

Bonneville Power Administration Projects

www.cbfwa.org/cfsite/maps/cfm

Maps of projects with restoration type. Project proposals listed at www.subbasin.org

Columbia River Inter-Tribal Fish Commission

Pacific Northwest, Tribal Successes under the Pacific Coastal Salmon

Recovery Fund; FY 2000-2002

www.critfc.org/text/pcsrf/crit_proj.html

A list with project name, year, cost, and location

Georgia Stream Restoration Sites

www.arches.uga.edu/\%7eesudduth/sites.html

Table of restoration projects

Idaho Department of Fish and Game

Middle Snake Subbasin Report

www.nwcouncil.org/fw/subbasinplanning/lowermidsnake/plan/Inventory_AppA_Projects.pdf

Lists by subbasin and includes project type, limiting factors, and monitoring comments

Minnesota River Basin Data Center

Minnesota River Basin Water Quality Improvement Grant Projects 1998-1999

mrbdc.mnsu.edu/projects/cshareARE9899/costshareARE.html

Map and a list of projects with sponsors, location, anticipated results, total project cost, grant amount, and project status

Montana Future Fisheries

Future Fisheries Improvement Project Funding and Status

www.fwp.state.mt.us/habitat/futurefisheries/content.asp

Table of projects listed with name, year, applicant, and cost

Montana Water Center

Montana Watersheds Project Directory

water.montana.edu/watersheds/projects/default.asp

Complex access database with abundant information and great contact information 


\section{Table 3. Continued}

Montana Water Center Case Studies

wildfish.montana.edu/Cases/casehistories.asp

Covers nine western states. Stories of the projects including background and contacts

Montana, University of Montana

ecorestoration.montana.edu/

Montana Ecosystem Restoration page describing rangeland and mine restoration with case histories and photo tours

New Mexico, Middle Rio Grande Bosque Initiative

mrgbi.fws.gov

Name, description, location, and timing details for river restoration projects

North Carolina

North Carolina Clean Water Management Trust Fund Database

www.cwmtf.net/

Lists approved projects and costs, organized by county

North Carolina Department of Natural Resources Wetlands Restoration Program

H2o.enr.state.nc.us/wrp/project/projects.htm

Case studies linked to a clickable map

North Carolina State University Stream Restoration Institute www.bae.ncsu.edu/programs/extension/wqg/sri/

Database of their projects and some case studies

Ohio Department of Natural Resources

Ohio Stream Management Guide No. 10

www.dnr.state.oh.us/water/pubs/fs_st/stfs10.htm

Descriptions and a map of biotechnical projects

Ohio State University, Stream and Ditch Design Projects

streams.osu.edu/projects.php

Case studies of channel reconfiguration projects in Ohio plus links to other states around the United States

Oregon Department of Fish \& Wildlife, Restoration and Enhancement Program www.dfw.state.or.us/ODFWhtml/InfoCntrFish/rneprogram/R\&EHistory.html Database linked to case studies about the projects

Oregon Plan Stories

The Oregon Plan for Salmon and Watersheds egov.oregon.gov/OPSW/stories/stories.shtml

A map linked to brief project descriptions with photos and captions

Oregon Trout

Oregon Trout Success Stories

www.ortrout.org/8success/success.html

Stories of the projects, with photos and contacts

Oregon Water Trust

www.owt.org/projects.html

Descriptions of water conservation projects

Oregon, Grand Ronde Model Watershed Program

www.fs.fed us/pnw/modelwatershed/

Database, maps, and descriptions for projects in this watershed in northeast Oregon

Palouse-Clearwater Environmental Institute www.pcei.org/water/restoration.htm

Includes photos, descriptions, and statistics on projects that this nonprofit has completed in northern Idaho and eastern Washington

Pennsylvania Department of Environmental Protection

Green Project Bank

www.dep.state.pa.us/greenprojectbank/

Searchable "Green Project Bank" so you can find a water restoration project 
Table 3. Continued

Regional Ecosystem Office, Interagency Restoration Database

www.reo.gov/restoration/index.htm

Contains federal agency projects for Washington, Oregon, and California including

Bureau of Land Management, USDA Forest Service, and Fish and Wildlife Service

Rhode Island Habitat Restoration

Restoring Coastal Habitats for Rhode Island's Future

www.edc.uri.edu/restoration/asp/projects.asp

Searchable database, map, and project descriptions for mostly coastal restoration projects

StreamNet

www.streamnet.org

Searchable database of projects in the Northwest United States

Washington Department of Ecology Water Quality and Aquatic Weed Removal Grants Programs www.ecy.wa.gov/programs/wq/plants/grants/projects.html

List of aquatic weed removal and water quality projects

Washington Department of Transportation

Washington State Highway System Fish Passage Program

www.wsdot.wa.gov/environment/fishpass/state_highways.htm\#Grant\%20Programs

Reports on funded and completed projects

Washington Interagency Committee for Outdoor Recreation

Salmon Recovery Funding Board Project Information System

www.iac.wa.gov/maps/default.asp

Map linked to project description, photos, location, and contact information

Washington State, City of Seattle

Salmon Habitat Projects

www.cityofseattle.net/salmon/salmonmaps/project.htm

A map linked to stories about salmon habitat restoration projects

Washington State, Uniform Environmental Project Reporting System

www.ueprs.wa.gov

Database of stream restoration projects among other environmental projects

Washington Water Trust

www.thewatertrust.org

List of projects by year

Wisconsin DNR

dnr.wi.gov/org/water/wm/dsfm/dams/removal.html

Case studies and a descriptive list of dam removals in Wisconsin

Wisconsin Trout Stamp Fiscal Reports

Expenditures of Inland Waters Trout Stamp Revenues FY 1998-2001

dnr.wi.gov/org/water/fhp/fisISh/pubs/pubindex.htm

Online PDF which contains descriptions of habitat restoration projects accomplished through Trout Stamp funds

Wisconsin, River Alliance of Wisconsin

www.wisconsinrivers.org/

List and descriptions of dam removals in Wisconsin

Wyoming Game \& Fish Department

A Compendium of Trout Stream Habitat Improvement Projects Done by the Wyoming

Game and Fish Department, 1953-1998, by Dr. N. Allen Binns

gf.state.wy.us/habitat/aquatic/compendium/index.asp

Each case history contains basic project data, color photos and graphs, and a summary

of fish and its habitat response to the project. The introductory section includes a

statewide analysis of these projects, including fish response, project costs, and structure types

USDA, U.S. Department of Agriculture; DNR, Department of Natural Resources. 
for similar efforts and as the structure upon which global datasets are developed and combined.

\section{Working toward an Ideal Stream Restoration Database}

NRRSS reviewed approximately 500 data sources for river restoration projects over three years and had developed a summary database with fields chosen to represent quantitative information on restoration projects (Bernhardt et al. 2005). This information was found to be available from many existing data sources and, although useful, lacked the depth and detail to really understand the outcomes of the project. A more effective data reporting scheme would include information on why the project was done, how it was planned, specific activities, types of professionals involved, and also how the project was monitored and evaluated, what successes and failures were identified, and project constraints. Based on the experience of compiling and analyzing synthesis database, we suggest that the types of information to be included in the ideal stream restoration database are:

- Contact information for participants

- Project dates (year started, year constructed, and year completed)

- Location information with latitude and longitude coordinates

- Project costs (broken down into specific components, including matching costs)

- Sources of funds, materials, and in-kind donations

- Explicit success criteria (i.e., measurable objectives) for relevant ecological, social, and economic objectives

- Species addressed and purpose (e.g., endangered species, non-native species)

- Project design and specific restoration practices

- Parameters monitored, frequency and duration of monitoring, protocols used, and whether reference sites were included as part of monitoring design

- Project constraints (e.g., time, money, staff availability, climate)

- Lessons learned (successes and failures) as the next step in adaptive management

- Links to case studies and/or other information.

In general, databases and lists provide basic facts but often lack the specificity and depth of case studies. The story behind the project often provides more insight than project cost or size information found in databases. Case studies also address human dimensions (e.g., social or economic) that are more difficult to quantify (e.g., community sentiment for stewardship, increased capacity to construct more beneficial projects, economic growth related to a restored site, and personal and spiritual rewards of restoration). For this reason, databases should not replace case studies, but through web links, the latter can continue to enhance the depth of the former.

In the future, researchers will be able to compare the effects of specific restoration techniques, particularly if a restoration database contains links to documents con- taining information on monitoring efforts, such as (1) monitoring criteria and protocols; (2) baseline and/or reference reach data; (3) as-built surveys; (4) postproject monitoring data; and (5) analytical summaries of major findings. However, in order for this to happen, increased availability of funds for monitoring and/or mandated monitoring funding will be necessary.

\section{Conclusions}

Without coordinated data tracking of restoration projects, we will be limited in our ability to draw conclusions about restoration effectiveness at scales larger than the individual project. In order to maximize the cost-effectiveness of restoration efforts as components of watershed and basin management strategies, we must begin to examine the cumulative impacts of restoration projects at these larger scales. At a minimum, various management agencies need some mechanism for sharing information about restoration projects in the same watershed between and across institutional boundaries. In the ideal scenario, seamless integration of project information at all scales will encourage and enable evaluation and research on populations of projects and facilitate information sharing between restoration practitioners, managers, and scientists.

\section{Acknowledgments}

The NRRSS working group is supported by the National Center for Ecological Analysis and Synthesis. The national effort received support from National Science Foundation, U.S. Geological Survey, the David and Lucille Packard Foundation, Altria, and the U.S. Environmental Protection Agency. Individual regional teams received support from the C. S. Mott Foundation, the Cooperative Research Centre for Freshwater Ecology, the McKnight Foundation, CalFed, the U.S. Bureau of Reclamation, University of Maryland, and the Maryland DNR. USGS National Biological Information Infrastructure provided personnel support; we particularly thank G. Cotter and M. Frame. We thank all data providers (17), particularly NOAA NWFSC, M. Ehrhart, S. D. Kunkoski, M. Wiley, and P. Steen; also R. Carlson and K. Ward, who provided us with previously synthesized regional databases. Specifically, thanks to Steve Katz and Chris Jordan at NOAA Fisheries, Mark Morehead at the University of Idaho, Boise, Christine Reichgott of Region 10 EPA, and Thomas Lamar and Laurie Gardes of the Palouse-Clearwater Environmental Institute, Moscow, Idaho. Views expressed here do not represent the views of any supporting organization or data provider. More information on the NRRSS effort is available at www.nrrss.umd.edu.

\section{LITERATURE CITED}

Bash, J., and C. M. Ryan. 2002. Stream restoration and enhancement projects: is anyone monitoring? Environmental Management 29:877-885.

Bernhardt, E. S., M. A. Palmer, J. D. Allan, G. Alexander, K. Barnas, S. Brooks, et al. 2005. Synthesizing U.S. river restoration efforts. Science 28:636-637. 
Bobbi, C. 1999. River management arising from willow removal. Pages 69-73 in Rutherfurd, I., and R. Bartley, editors. Proceedings of the Second Australian Stream Management Conference: Volume 1. Adelaide, Australia. Cooperative Research Centre for Freshwater Ecology, Monash University, Victoria, Australia.

Clewell, A., and J. P. Rieger. 1997. What practitioners need from restoration ecologists. Restoration Ecology 5:350-354.

FISRWG (The Federal Interagency Stream Restoration Working Group: 15 Federal agencies of the U.S. government). 2001. Stream corridor restoration; principles, processes, and practices. URL http://www. usda.gov/stream_restoration [accessed on 6 December 2004]

Henry, C. P., C. Amoros, and N. Roset. 2002. Restoration ecology of riverine wetlands: a 5 year post-operation survey on the Rhône River, France. Ecological Engineering 18:543-554.

Jungwirth, M., S. Muhar, and S. Schmutz. 2002. Re-establishing and assessing ecological integrity in riverine landscapes. Freshwater Biology 47:867-887.

Kershner, J. L. 1997. Monitoring and adaptive management. Pages 116-134 in J. E. Williams, C. A. Wood, and M. P. Dombeck, editors. Watershed restoration: principles and practices. American Fisheries Society, Bethesda, Maryland.

Kondolf, G. M., and E. R. Micheli. 1995. Evaluating stream restoration projects. Environmental Management 19:1-15.

Ladson, A., G. Gerrish, G. Carr, and E. Thexton. 1997. Willows along Victorian Waterways; towards a willow management strategy. Department of Natural Resources and Environment, Victoria, Australia.
Lake, P. S. 2001. On the maturing of restoration: linking ecological research and restoration. Ecological Management and Restoration 2:110-115.

Landers, D. H. 1997. Riparian restoration: current status and the reach to the future. Restoration Ecology 5:113-121.

Leopold, L. 1997. Let rivers teach us. Understanding River and Stream Systems, U.S.D.A. Natural Resources Conservation Service Symposium. Berkeley, California, 18 November 1997. URL ftp://ftpfc.sc.egov.usda.gov/WSI/pdffiles/Let_Rivers_Teach_Us-Luna_ Leopold_1997.pdf [accessed 28 March 2005]

Mayer, P., E. Striz, R. Shedlock, E. Doheny, and P. Groffman. 2004. The effects of ecosystem restoration on nitrogen processing in an urban Mid-Atlantic Piedmont stream. Pages 536-554 in K. G. Renard, S. A. McElroy, W. J. Gburek, E. H. Canfield, and R. L. Scott, editors. First Interagency Conference on Research in the Watersheds, October 2003. Tucson, Arizona. U.S. Department of Agriculture, Agricultural Research Service, Washington, D.C.

NRC (National Research Council). 1992. Restoration of aquatic ecosystems: science, technology, and public policy. National Academy of Science, National Academy Press, Washington, D.C.

Palmer, M. A., E. Bernhardt, E. Chornesky, S. Collins, A. Dobson, C. Duke, et al. 2004. Ecology for a crowded planet. Science 304:28.

Palmer, M. A., E. S. Bernhardt, J. D. Allan, G. Alexander, S. Brooks, J. Carr, et al. 2005. Standards for ecologically successful river restoration. Journal of Applied Ecology 42:208-217.

Shields, F. D. Jr, R. R. Copeland, P. C. Klingeman, M. W. Doyle, and A. Simon. 2003. Design for stream restoration. Journal of Hydraulic Engineering 129:575-584. 